\title{
Increasing of Food and Bioenergy Potato Resources by Microbial Influence on Tubers Phytohormonal Status
}

\author{
Elena I. Kiprushkina ${ }^{1}$, Denis A. Baranenko ${ }^{2},{ }^{1-2}$ ITMO University
}

\begin{abstract}
Potato and its by-products became a promising both food and bioenergy resource. The determination of the bacteriaantagonists influence on phytohormone status and productivity of potato tubers was studied. The indole-3-acetic acid content during the dormancy end and germinating in the tubers treated with Bacillus subtilis $\mathrm{Ch}-13$ was fewer than in the control samples. L-tryptophan significant quantity compared to the control was found in the treated tubers in a state of physiological dormancy (more than 2-fold) and especially during active germination (43 times greater). Average potato yield increase at treated fields was of $18.8 \%$.
\end{abstract}

Keywords - Biological control, Solanum tuberosum, Bacillus subtilis Ch13, hormones, HPLC.

\section{INTRODUCTION}

Potato (Solanum tuberosum) is a traditional widespread crop. It is the third crop in order of importance after wheat $(630 \mathrm{Mt})$ and rice $(608 \mathrm{Mt})$ consumed by men in amount of over $300 \mathrm{Mt}$ every year [1]. It is an important part of the diet and a source of starch, vitamin $\mathrm{C}$ and potassium for people in both developed and developing countries. In recent years, potato by-products became also regarded as a promising resource for the production of biofuels [2], [3]. These byproducts are cull potatoes and potato processing waste and they are approximately half of all produced potato [4]. Peels are the major waste of potato processing, they amount from $15 \%$ to $40 \%$ of produced potato, depending on the procedure applied [5].

Potato peel features a high potential for producing biofuel [6]. Enzymatic hydrolysis with a combination of three enzymes, released $18.5 \mathrm{~g} / \mathrm{l}$ reducing sugar and produced $7.6 \mathrm{~g} / \mathrm{l}$ of ethanol after fermentation by Saccharomyces cerevisae var. bayanus [7]. The strong advantages of steam potato peels over other feedstock types are that they do not compete with the food and feed industries for biomass and land [8]. Steam potato peels are traditionally used as fodder and also they are perspective feedstock for producing biohydrogen. Recent researches show that using potato steam peels to produce hydrogen along with feeding animals with its by-products offer more environmental benefits than using the potato steam peels directly for animal fodder [9]. There was shown the possibility of electricity generation thought the butanol production from potato peel fermentation by Clostridium acetobutylicum [10].

Increasing the productivity of potato by means of biotechnology is an important task, since it allows to provide the population with more food and energy with less resource, as well as to refuse adverse anthropogenic factors of production. Mineral fertilizers are one of these factors. Excessive use of mineral fertilizers causes disruption of normal biological, chemical and physical processes in soil, leading to its degradation and destruction of the organic component. As the total soil area of world potato production is about 20 million hectares, fertilizers and pesticides used in it have a great impact on the global environment [11].

One of the options of "green" agricultural technology is the use of microbiological preparations. Microbial preparations may directly affect plant pathogenic microorganisms, as well as strengthen plants own defense mechanisms [12-14]. Plants own defense systems operate with hormones that act like signal molecules or chemical messengers that control plant growth and development. The phytohormones are synthesized in the certain organs of the plant and can be transported to other sites, where they start specific biochemical, morphological or physiological responses. In addition, numerous soil microorganisms also produce phytohormones. There are five recognized classes of phytohormones, regarded as the "classical five": auxins, gibberellins, cytokinins, abscisic acid and ethylene.

A study of the hormonal balance in the tissues of potatoes having a resting stage in ontogeny is necessary for understanding the impact of biological control agents on the regulation of plant growth and development. However, the results of such studies can be used to develop ways to control the functions of rest and growth of tubers and other storage organs of plants.

Rhizosphere bacteria can use several different pathways for auxins biosynthesis. Auxins in the culture fluid of Bacillus subtilis Ch-13 were analyzed with help of HPLC in the study of the phytostimulating properties of this strain [15], [16]. Analysis showed the production of four auxins by the strain: indole-3-lactic acid, indole-3-carboxylic acid, indol-3aldehyde and indole-3-acetic acid (IAA). Indol-3-aldehyde $(7.19 \mu \mathrm{g} / \mathrm{ml})$ and indole-3-lactic acid $(2.87 \mu \mathrm{g} / \mathrm{ml})$ were the most intensively produced.

There was made a suggestion about the possible impact of bacteria-antagonists on phytohormone status of tubers, the synthesis of exogenous hormones with the possibility of human-induced regulation of hormonal metabolism in plants. It gives a possibility of altering the physiology of a host plant in the direction of increasing resistance to stress and effects of abiotic environmental factors. Together with an antagonistic effect against pathogens it will lead to an increase in the 
overall sustainability and productivity of potato after the processing of products to be put on a long-term storage, of seed material and of vegetative plants with biocontrol strains.

The decisive factors in the regulation of plant transition from physiological dormancy to active growth are concentration and ratio of certain plant hormones in a cell, as well as the competence of the cell, i.e. the presence or absence of substances that mediate hormone action. In this regard, the aim of the study was the determination of the bacteriaantagonists influence on phytohormone status and productivity of potato tubers. IAA, L-tryptophan and abscisic acid (ABA) were analyzed in the potato peel tissues, as they play an important regulatory function in plant tissues during the dormancy end and during the transition to the active growth.

\section{MATERIALS AND METHODS}

\section{A. The Plant and Bacterial Materials}

Potato tubers (Solanum tuberosum) of Nevsky variety were treated with bacterial suspension of antagonistic bacteria Bacillus subtilis Ch-13 $\left(10^{9} \mathrm{CFU} / \mathrm{ml}\right)$. The tubers were collected from experimental fields of the All-Russia Research Institute for Agricultural Microbiology (ARRIAM), Pushkin, Saint-Petersburg, Russia. The strains of antagonistic bacteria used in this study were isolated from soil in Moldova and deposited in ARRIAM. The tubers were bacterized with a hand sprayer immediately before long-term storage with 11 of bacterial suspension to each $100 \mathrm{~kg}$ of potatoes. The potato has been stored at the temperature $+3{ }^{\circ} \mathrm{C} \pm 1{ }^{\circ} \mathrm{C}$ and the relative humidity $90 \%-95 \%$ for 8 months. Planting material was treated with 11 of bacterial suspension to each $1000 \mathrm{~kg}$ of tubers, vegetating plants in the phase of the first leaves appearance and in the phase of appearance of flower buds before flowering - with 21 of suspension to each hectare.

\section{B. Preparation of Pathogen Inoculum}

Phytophthora infestans were grown and maintained at $+15^{\circ} \mathrm{C}$ in Petri dishes (diameter of $9 \mathrm{~cm}$ ) on rye agar. Sporangial suspensions were prepared from 14-day-old cultures by feeling the plates with a sterile solution of $0.0125 \%$ Tween 80 in deionised water and gently scraping the mycelium with a spatula.

Pathogenesis was simulated by infectioning slices of whole potato tubers with a biotrophic fungus $P h$. infestans suspension $\left(1 \cdot 10^{4}\right.$ zoospores $\left./ \mathrm{ml}\right)$, followed by inoculation with a bacterial suspension of Bacillus subtilis Ch-13 $\left(10^{9} \mathrm{CFU} / \mathrm{ml}\right)$. The incubation of the samples lasted for $48 \mathrm{~h}$ at $+25^{\circ} \mathrm{C}$.

Bacillus subtilis Ch-13 was grown in a liquid nutrient medium having the following composition: peptone $20 \mathrm{~g} / \mathrm{l}$, glycerol $10 \mathrm{~g} / \mathrm{l}, \mathrm{MgSO}_{4} 1.5 \mathrm{~g} / \mathrm{l}, \mathrm{K}_{2} \mathrm{HPO}_{4} 1.5 \mathrm{~g} / \mathrm{l}$; using a shaker or a fermenter at $+37^{\circ} \mathrm{C}$ for $24 \mathrm{~h}-36 \mathrm{~h}$ until the titer of the culture fluid became $10^{9} \mathrm{CFU} / \mathrm{ml}$.

\section{Isolation of IAA, L-tryptophan and ABA from Potato Peel}

The analyzed sample of $50 \mathrm{~g}$ of crude potato peels was cut with an electric laboratory mill and filled with $100 \mathrm{ml}$ of $50 \%$ ethyl alcohol. Extraction was performed for $1 \mathrm{~h}$ with shaking at $130 \mathrm{rpm}$. After extraction the plant material was separated by filtration, the separated extract was evaporated under vacuum at $+45^{\circ} \mathrm{C}$ to a volume of $\sim 20 \mathrm{ml}$ and then centrifuged for $10 \mathrm{~min}$ at $12,000 \mathrm{rpm}$ to remove fine particles. The resulting aqueous solution was passed through a $\mathrm{C}_{18}$ column for purification, after which the column was additionally washed with $3 \mathrm{ml}$ of $20 \%$ methanol. The resulting sample was extracted with its twice volume of ethyl acetate, acidified with $4 \mathrm{~N} \mathrm{HCl}$ to $\mathrm{pH}$ of 3.0. The resulting extract was evaporated to dryness on a vacuum rotary evaporator at $+45^{\circ} \mathrm{C}$ and dissolved in $0.5 \mathrm{ml}$ of $20 \%$ methanol followed by filtration through a nylon membrane filter (pore diameter of $0.45 \mu \mathrm{m}$ ).

\section{Analysis of the Contents of IAA, L-tryptophan and ABA in Potato Peel}

Analysis of IAA and L-tryptophan was performed with HPLC system Jasco LC-900 (Jasco International Co., Japan), equipped with a Rheodyne doser valve (Cotati, USA), a high pressure pump PU-980, degassing module DG-980-50, gradient module LG-980-02, ultraviolet detector UV-975 $(220 \mathrm{~nm}$ ), fluorescence detector FP-920 (excitation at $280 \mathrm{~nm}$, emission at $350 \mathrm{~nm}$ ) and computer system with a Borwin software (JMBS Developments, France), connected to the HPLC system via Jasco LC-NET. The metabolites were separated on a reversed phase column $\mathrm{C}_{18}$ LiChrosorb RP-18 (Sigma, USA) with dimensions of $2504.6 \mathrm{~mm}$, using a mobile phase of water : acetonitrile : acetic acid (82: $18: 0.2 \mathrm{v} / \mathrm{v} / \mathrm{v})$. The flow rate was $0.9 \mathrm{ml} / \mathrm{min}$ and the column temperature of $+31{ }^{\circ} \mathrm{C}$.

Analysis of the abscisic acid was carried out first using a linear gradient buffer from acetonitrile : water : acetic acid 20 : $80: 0.2(\mathrm{v} / \mathrm{v} / \mathrm{v})$ to $70: 30: 0.2(\mathrm{v} / \mathrm{v} / \mathrm{v})$ for $35 \mathrm{~min}$, then in isocratic mode for $10 \mathrm{~min}$. The flow rate was $0.9 \mathrm{ml} / \mathrm{min}$, the column temperature of $+31^{\circ} \mathrm{C}$, UV detection at $220 \mathrm{~nm}$.

\section{RESULTS AND DISCUSSION}

\section{A. Influence of Bacillus Subtilis Ch-13 on Phytohormonal Status of Potato Tubers}

Induction of potato dormancy, inhibition of cell growth, stress resistance increase, accumulation of reserve substances in the resting organs are due to the presence of ABA [17]. Germination after deep dormancy is first of all due to an increase in the activity of auxins. As to morphogenetic effect of cytokinins, it is aimed at growth and development of the above-ground mass and retention of cell aging; gibberellins cause tension and induce flowering; ethylene promotes ripening and leaf fall.

Plants hormonal metabolism is one of the most sensitive types of exchange, which responds to external stimuli. In this regard, in all cases of treatments of seed materials or vegetative plants with pesticides, biologically active substances or protective and stimulating biological products, it should be taken into account not only their biological effectiveness, but also their influence on protected plants hormonal metabolism.

Tubers have a higher resistance to diseases during deep rest. Since there is a biochemical relationship between the 
functions of dormancy and stability to the unfavorable factors, it is important to use technologies, which act on the growth processes and do not reduce this stability. It is important to study the effect of bacteria-antagonists and their metabolites on tubers dormancy period duration and resistance to disease.

The duration of dormancy period is a varietal characteristic. Its ending is accompanied by a decrease in the ABA content in the skin and the peripheral part of potato parenchyma. In this period treated tubers contained less ABA and had earlier germination than the control untreated tubers (Table I). It is known that ABA hormone exerts a strong growth inhibiting effect in concentrations of $0.05 \mathrm{mg} / \mathrm{g}-0.5 \mathrm{mg} / \mathrm{g}$. In the obtained experiment data this hormone content was lower than the minimum concentration in the specified range. ABA is an antagonist of auxins. Low ABA content reduces the duration of dormancy and increases the tuber germination capacity. The control group tubers differed from the treated ones in a delayed germination. The delay was on average of 15-17 days. Length of germs was $10-12 \mathrm{~mm}$ and $3-5 \mathrm{~mm}$ in treated and control samples, respectively, after 180 days of storage.

Dormancy induction, its duration and termination are associated with a change in the ratio of growth factors and inhibitors. Experiment data shows that potato treatment with biological control agents alters the hormonal balance, resulting in a less intense increase in the level of auxins (IAA), and a reduce of the $\mathrm{ABA}$ amount. However, the numerical value of the ratio between IAA and $\mathrm{ABA}$ hormones in treated tubers differs slightly from the control (Table I).

Chromatographic analysis of auxins from the potato tubers peel extract showed the presence of intense peaks with the retention time of 6-8 min and $18 \mathrm{~min}$, corresponding to the active absorption of L-tryptophan and IAA, respectively. The IAA content in the treated tubers during the dormancy end and germinating was fewer than in the control samples. L-tryptophan is the immediate precursor of the IAA biosynthesis. Its significant quantity compared to the control was found in the treated tubers in a state of physiological dormancy (more than 2-fold) and especially during active germination (43 times greater).

IAA is synthesized from L-tryptophan in two steps, which are catalyzed by enzymes tryptophan monooxygenase and indoleacetamide hydrolase [18]. Perhaps plant-bacterial interaction increases activity and the content of these enzymes. In this case bacterial cells and their metabolic products can affect the synthesis and conversion of this amino acid in the auxins. Potato treatment with bacillary cells has a prolonged effect with increasing synthesis of auxin precursors, which are the needed growth promoters for the tubers preparation to reproduce in the second vegetation year. Auxins often undergo further transformations after formation. Thus, IAA can bind to carbohydrates, amino acids or proteins, forming inactive (reserve) forms. Probably, low levels of IAA and excess amounts compared to control of its precursor L-tryptophan, that were obtained in the study, are due to the formation of such inactive IAA conjugates. If necessary, IAA may release from these compounds and restore its physiological activity. Thus, the chromatographic analysis demonstrated that the studied biocontrol strain produces exometabolites having phytohormone properties.

TABLE I

CONTENTS OF ABA, IAA AND L-TRYPTOPHAN IN THE POTATO PEEL AFTER DiFFERENT BIOPREPARATION TREATMENT

\begin{tabular}{|c|c|c|c|c|c|}
\hline & \multirow{2}{*}{$\begin{array}{c}\mathbf{A B A}, \\
\mathbf{n g} / \mathbf{g}\end{array}$} & \multirow{2}{*}{$\begin{array}{l}\text { IAA, } \\
\text { ng/g }\end{array}$} & \multirow{2}{*}{$\begin{array}{c}\text { L-tryptophan, } \\
\text { ng/g }\end{array}$} & \multicolumn{2}{|c|}{ Ratio } \\
\hline & & & & IAA/ABA & L-tryptophan/IAA \\
\hline \multicolumn{6}{|c|}{ End of dormancy ( 150 days after the storage start) } \\
\hline Control (without treatment) & 120.49 & 299.40 & 6.57 & 2.49 & 0.02 \\
\hline B. subtilis Ch-13 & 44.78 & 78.13 & 12.99 & 1.75 & 0.17 \\
\hline \multicolumn{6}{|c|}{ Germination (210 days after the storage start) } \\
\hline Control (without treatment) & - & 65.23 & 6.11 & - & 0.09 \\
\hline B. subtilis Ch-13 & - & 37.04 & 263.77 & - & 7.12 \\
\hline B. subtilis Ch-13+P.infestans & - & 29.93 & 121.76 & - & 4.07 \\
\hline
\end{tabular}

The chromatograms did not show any component with the retention time corresponding to the retention time for $\mathrm{ABA}$ standard in all samples during germination. This means that after 210 days from the storage start during the active germination of tubers there were no detectable amounts of abscisic acid in any of the analyzed samples.

Plant body infectioning is accompanied by changes of hormone levels in infected cells and in the whole plant. The obtained data show that in the system of tuber-bacillibiotrophic pathogen ( $P$. infestans) there was a slight decrease in IAA compared to the two-component system of tuberbacilli. In contrast to the treated samples auxin level in the control tubers was higher in 2 or more times (Table I). Inoculation of potato with bacillary cells helped to stabilize the level of auxin during infection. At the same time, the tuber-bacilli system had two times and more the content of L-tryptophan comparing to the three-component system. Probably under extreme ambient conditions as the pathogenesis the plant increases the overall level of metabolic processes, resulting in a rapid metabolismsm of the main auxin precursor.

Probably, an increased content of IAA may take a part in plant cell walls loosening, infectious microorganisms introduction facilitation and reducing activity of protective peroxidase enzyme. Yarullina et al. showed that after plant infectioning with a pathogen the IAA content in the tissues of the plant increases [19]. Hormones are involved in the response to almost all the stresses, as the role of coordinators 


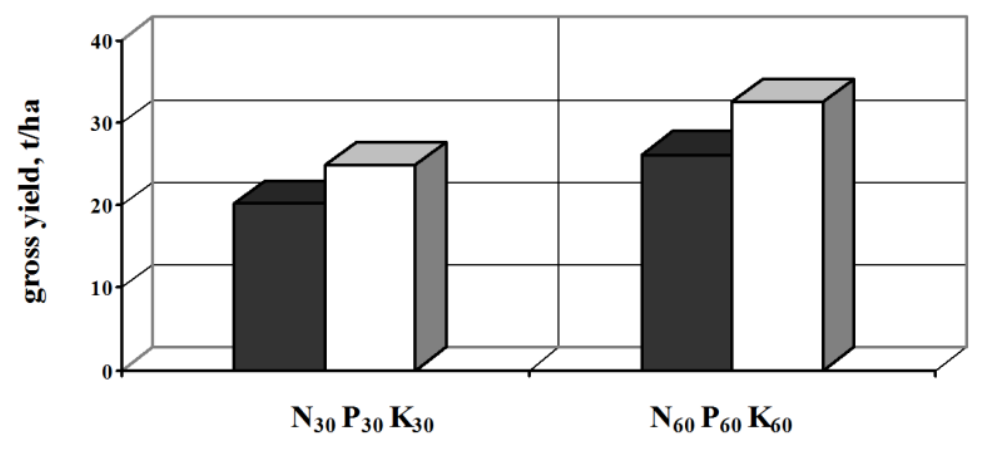

\section{$\square$ Control (no treatment) $\square$ B.subtilis Ch13}

Fig. 1. Yield of Nevsky variety potato after biological treatment at different mineral nutrition backgrounds.

of various functions of the plant organism belongs to them. They act as a kind of trigger that starts a cascade of biochemical reactions occurring in sequence, leading to stress resistance, or, conversely, to increased sensitivity to adverse environmental factors.

\section{B. Influence of Bacillus Subtilis Ch-13 on Productivity of Potato Tubers}

As shown above, bacteria of the genus Bacillus induce biosynthetic capabilities of plant cells. It was decided to study how this can influence productivity of tubers at different amounts of applied mineral fertilizers. Tests were carried out during the growing season at the experimental field spatially isolated from industrial plantations. Potatoes were grown by the conventional technology. Efficiency of the biological potato treatment was evaluated for different mineral nutrition backgrounds introduced before planting at the rate of the active substance $\mathrm{N}_{60} \mathrm{P}_{60} \mathrm{~K}_{60}$ and $\mathrm{N}_{30} \mathrm{P}_{30} \mathrm{~K}_{30}$ as a starter fertilizer. Plots on the same field without conducting the biological treatment were used as a control.

Potato of the biologically treated variants had better nodulation that favorably affected the yield (Fig. 1). The increase in the potato yield was of 4.72 tons per hectare at the reduced agricultural background (30) and 6.34 tons per hectare at the increased agricultural background (60).

Bioprocessing efficiency increases with the dose of the active ingredient of mineral fertilizer. Fertilizer containing basic elements of nutrition and entered in a dose of $\mathrm{N}_{60} \mathrm{P}_{60} \mathrm{~K}_{60}$ provided an effective improvement of soil fertility. However, the use of the microbial preparation at the reduced agricultural background (30) gives a yield increase equal to the control variant without biological treatment obtained at the improved mineral nutrition (60).

The data obtained at the experimental field was confirmed at a real potato production on the territory of three farms in Leningrad region. The average area of the fields exposed to biological treatment was 34.6 hectares. The average area of the control fields without biotreatment was 51.3 hectares. Average potato yield increase at the treated areas was of $18.8 \%$.
Microbiological preparations have some advantages in terms of cost of materials, energy and renewable resources. In most cases low-value materials, agricultural and food residues are used for their production. In Russian Federation about $35 \%$ of agricultural production costs are accounted to mineral fertilizers [20]. Thus, a two-fold reduction in the amount of applied mineral fertilizers, while maintaining the productivity of potato by use of biological treatment is economically advantageous.

\section{CONCLUSION}

The studied strain increases the stability and yield of potato, which can be explained not only by the direct action of bacteria-antagonists Bacillus subtilis Ch-13 on phytopathogens, but also by the activation of defense system of the plants themselves. This resistance induction of the treated potato is associated with changes in hormonal status, which in turn may be due to the synthesis of auxin like substances and their precursors, introduced in the potato epiphytic microflora by bacteria-antagonists.

Biological means of protection based on bacteriaantagonists Bacillus subtilis Ch-13 induce the plant cell biosynthesis possibilities, changing the status of tubers phytohormones. Biocontrol microorganisms may be effective components of an integrated system of plant protection that improve the productivity of agricultural crops.

Microorganisms isolated from nature and introduced again into the natural environment as biological products, in addition to the positive impact on the reproduction of soil fertility, increase crops productivity at lower doses of mineral fertilizers, reduce the agrochemical load on plants, ensure the environmental safety of farming, do not cause environmental and food pollution and also have no adverse effects on beneficial insects - pollinators of plants and wild mammals.

Increasing the yield of potato using microbiological preparations is particularly important among the transition to renewable energy sources, which can be obtained from it. Benefits and expediency of all stages of resource life cycle will increase at lesser environmental, economic and resource load at the production of initial raw materials. 


\section{ACKNOWLEDGEMENT}

This work was partially financially supported by Government of Russian Federation, Grant 074-U01.

\section{REFERENCES}

1. Haverkort, A. J., Struik, P. C., Visser, R. G. F., Jacobsen, E. Applied biotechnology to combat late blight in potato caused by Phytophthora infestans. Potato Research, 2009, vol. 52, No. 3, pp. 249-264. http://dx.doi.org/10.1007/s11540-009-9136-3

2. Kim, S., Dale, B. E. Global potential bioethanol production from wasted crops and crop residues. Biomass and Bioenergy, 2004, vol. 26, pp. 361-375. http://dx.doi.org/10.1016/j.biombioe.2003.08.002

3. Lal, R. World crop residues production and implications of its use as a biofuel. Environment International, 2005, vol. 31, pp. 575-584. http://dx.doi.org/10.1016/j.envint.2004.09.005

4. Charmley, E., Nelson, D., Zvomuya, F. Nutrient cycling in the vegetable processing industry: Utilization of potato by-products Canadian Journal of Soil Science, 2006, vol. 86, No. 4, pp. 621-629. http://dx.doi.org/10.4141/S05-118

5. Schieber, A., Stintzing, F. C., Carle, R. By-products of plant food processing as a source of functional compounds - recent developments. Trends in Food Science \& Technology, 2001, vol. 12, No. 11, pp. 401-413. http://dx.doi.org/10.1016/S0924-2244(02)00012-2

6. Liang, S., McDonald, A. G. Chemical and thermal characterization of potato peel waste and its fermentation residue as potential resources for biofuel and bioproducts production. Journal of Agricultural and Food Chemistry, 2014, vol. 62, No. 33, pp. 8421-8429. http://dx.doi.org/10.1021/jf5019406

7. Arapoglou, D., Varzakas, T., Vlyssides, A., Israilides, C. Ethanol production from potato peel waste (PPW). Waste Management, 2010, vol. 30, No. 10, pp. 1898-1902.

http://dx.doi.org/10.1016/j.wasman.2010.04.017

8. Djomo, S. N., Blumberga, D. Comparative life cycle assessment of three biohydrogen pathways. Bioresource Technology, 2011, vol. 102, No. 3, pp. 2684-2694. http://dx.doi.org/10.1016/j.biortech.2010.10.139

9. Djomo, S. N., Humbert, S., Blumberga, D. Life cycle assessment of hydrogen produced from potato steam peels. International Journal of Hydrogen Energy, 2008, vol. 33, No. 12, pp. 3067-3072. http://dx.doi.org/10.1016/j.ijhydene.2008.02.006

10. Arifin, Y., Tanudjaja, E., Dimyati, A., Pinontoan, R. A Second Generation Biofuel from Cellulosic Agricultural By-product Fermentation Using Clostridium Species for Electricity Generation. Energy Procedia, 2014, vol. 47, pp. 310-315. http://dx.doi.org/10.1016/j.egypro.2014.01.230

11. Conway, G. R., Pretty, J. N. Unwelcome harvest: agriculture and pollution. Routledge: Taylor \& Francis, 2013.

12. Krechel, A., Faupel, A., Hallmann, J., Ulrich, A., Berg, G. Potatoassociated bacteria and their antagonistic potential towards plantpathogenic fungi and the plant-parasitic nematode Meloidogyne incognita (Kofoid \& White) Chitwood. Canadian Journal of Microbiology, 2002, vol. 48, No. 9, pp. 772-786.

13. Stephan, D., Schmitt, A., Carvalho, S. M., Seddon, B., Koch, E. Evaluation of biocontrol preparations and plant extracts for the control of Phytophthora infestans on potato leaves. European Journal of Plant Pathology, 2005, vol. 112, No. 3, pp. 235-246.

http://dx.doi.org/10.1007/s10658-005-2083-1

14. Grosch, R., Faltin, F., Lottmann, J., Kofoet, A., Berg, G. Effectiveness of 3 antagonistic bacterial isolates to control Rhizoctonia solani Kühn on lettuce and potato. Canadian Journal of Microbiology, 2005, vol. 51, No. 4, pp. 345-353. http://dx.doi.org/10.1139/w05-002

15. Chebotar, V. K., $\quad$ Makarova, N. M., Shaposhnikov, A. I., Kravchenko, L. V. Antifungal and phytostimulating characteristics of Bacillus subtilis Ch-13 rhizospheric strain, producer of bioprepations. Applied Biochemistry and Microbiology, 2009, vol. 45, No. 4, pp. 419-423. http://dx.doi.org/10.1134/S0003683809040127

16. Chebotar, V. K., Petrov, V. B., Shaposhnikov, A. I., Kravchenko, L. V. Biochemical criteria for estimation of agronomic valuable properties of bacilli used for development of microbial preparations. Agricultural Biology, 2011, vol. 3, pp. 119-122.

17. Destefano-Beltrán, L., Knauber, D., Huckle, L., Suttle, J. C. Effects of postharvest storage and dormancy status on ABA content, metabolism, and expression of genes involved in ABA biosynthesis and metabolism in potato tuber tissues. Plant Molecular Biology, 2006, No. 61, pp. 687-697. http://dx.doi.org/10.1007/s11103-006-0042-7

18. Comai, L., Kosuge, T. Involvement of plasmid deoxyribonucleic acid in indoleacetic acid synthesis in Pseudomonas savastanoi. Journal of Bacteriology, 1980, vol. 143, No. 2, pp. 950-957.

19. Yarullina, L. G., Troshina, N. B., Maksimov, I. V. Participation of IAA in suppression of protective reactions in wheat plants infected by smut agent. Micology and Phytopathology, 2006, vol. 40, No. 2, pp. 160-165.

20. Ganenko, I. Costs rising again. Agroinvestor, 2011, vol, 42, No. 7, pp. 23-29. (in Russian)

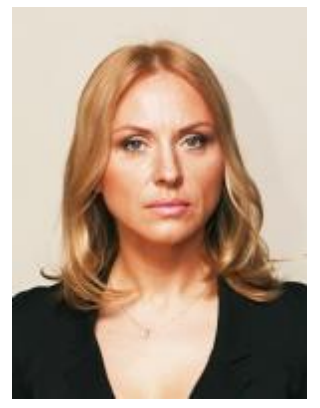

Elena Kiprushkina was born in 1970, in 1992 graduated and in 1995 defended $\mathrm{PhD}$ thesis at the Institute of Refrigeration and Biotechnologies, ITMO University. Since 2005 works there as an assistant professor. Research interests: plant products biological control agents, microbial-plant interactions, stress mechanisms, post-harvest biotechnology. E-mail: kipelena @yandex.ru

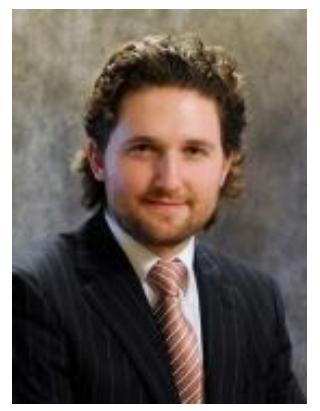

Denis Baranenko was born in 1981, in 2003 graduated and in 2006 defended $\mathrm{PhD}$ thesis at the Institute of Refrigeration and Biotechnologies, ITMO University. Since 2006 works there as an assistant professor, from 2011 directs the work of a research laboratory. Research interests: resource and energy saving, food biotechnology.

Phone: +7-812-315-3015

E-mail: denis.baranenko@niuitmo.ru 